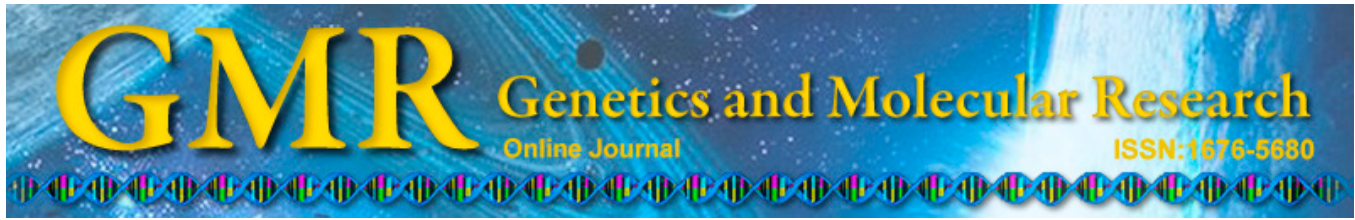

\title{
Isolation of 1-aminocyclopropane-1- carboxylate synthase gene from Oncidium Gower Ramsey
}

G.H. Yang ${ }^{1,2}$ and J.P. Liu ${ }^{1}$

${ }^{1}$ Key Laboratory of Protection and Development Utilization of Tropical Crop Germplasm Resources, Ministry of Education, College of Agronomy, Hainan University, Haikou, Hainan Province, China ${ }^{2}$ Sanya Science \& Technology Academy for Crop Winter Multiplication, Sanya, China

Corresponding author: J.P. Liu E-mail: liu3305602@163.com

Genet. Mol. Res. 13 (4): 8480-8488 (2014)

Received September 26, 2013

Accepted February 21, 2014

Published October 20, 2014

DOI http://dx.doi.org/10.4238/2014.October.20.24

ABSTRACT. A full-length cDNA of a 1-aminocyclopropane-1-
carboxylate synthase (ACS) family member from Oncidium, named
OnACS1 (GenBank accession No. JQ822087) was cloned and
characterized by reverse transcription polymerase chain reaction
and rapid amplification of cDNA ends technology. The full-length
cDNA was 1586 bp, including a 1308-bp open reading frame, a 105-
bp 5' untranslated region (UTR), and 173-bp 3' UTR, encoding 436
amino acids. The deduced amino acid sequence of OnACS1 shares
85,84 , and $83 \%$ homology with ACS proteins of Cattleya bicolor,
Dendrobium crumenatum, and Phalaenopsis hybrid, respectively.
Prokaryotic expression and sodium dodecyl sulfate polyacrylamide
gel electrophoresis showed that a specific band was produced and was
consistent with the predicted protein size. A tissue-specific manner of
OnACS1 expression was observed, and it was predominantly expressed
in the gynostemium. The OnACS1 expression in the sepals and 
gynandria was upregulated by $1 \%$ ethephon treatment.

Key words: 1-Aminocyclopropane-1-carboxylate synthase; Oncidium; Ethylene; Floral senescence

\section{INTRODUCTION}

Ethylene, a small gaseous phytohormone, plays an important regulatory role in various aspects of plant growth and development such as ripening and senescence (Abeles et al., 1992; Yang and Hoffman, 1984). In the biosynthesis of ethylene in higher plants, the last two steps are the conversion of $S$-adenosylmethionine to 1-aminocyclopropane-1-carboxylic acid (ACC), which is catalyzed by ACC synthase (ACS), and the conversion of ACC to ethylene, which is catalyzed by ACC oxidase (Adams and Yang, 1979; Yang and Hoffman, 1984; Kende, 1993). Because ACS is generally considered as the rate-limiting step in the committed ethylene biosynthetic pathway, a significant effort has been directed at the isolation and characterization of ACS. ACS is composed of a larger gene family (Zarembinski and Theologis, 1994; Lin et al., 2009), and genes encoding ACS have been isolated and characterized from a number of flowering plants such as carnation (Park et al., 1992; Henskens et al., 1994) and Phalaenopsis orchid (Bui and O'Neill, 1998).

The Oncidium Gower Ramsey is a commercially important orchid cut flower. We are interested in the regulation of ethylene biosynthesis in Oncidium Gower Ramsey flowers during senescence. As a first step toward this goal, we report that an ACS gene was isolated from Oncidium Gower Ramsey flower tissue, and we show that it was differentially expressed in different organs.

\section{MATERIAL AND METHODS}

\section{Plant material}

Greenhouse-grown Oncidium Gower Ramsey 'Gold2' plants were obtained from a commercial grower. Roots, stems, leaves, and floral parts (labella, petals, sepals, and gynandria) were collected in liquid $\mathrm{N}_{2}$, pulverized into a fine powder, and stored at $-80^{\circ} \mathrm{C}$ until subsequent use in RNA isolation. The effects of ethephon on ACS gene expression in sepals and gynandria were tested. Floral parts were smeared with $1 \%$ ethephon and sealed in plastic bags for different lengths of time $(0,6,12,24$, and $48 \mathrm{~h})$. Tissue samples of sepals and gynandria were then frozen in liquid nitrogen and stored at $-80^{\circ} \mathrm{C}$ until RNA extraction.

\section{RNA extraction and $O n A C S 1$ gene isolation}

Total RNA was extracted from frozen tissue of floral parts using a previously described method (Yang and Liu, 2011). The first strand of cDNA was synthesized using the RevertAidTM First Strand cDNA Synthesis Kit (MBI Fermentas, JINGMEI BIOTECH CO., LTD., Shenzhen, China) according to the manufacturer protocol. To amplify the cDNA fragment of OnACS1, we used specific primers ACS-F and ACS-R (Table 1) that were designed from the given nucleotide sequences registered on the database (accession Nos. AY504664, EF488013, and AF004663). Reactions were subjected to 30 cycles of $95^{\circ} \mathrm{C}$ for $30 \mathrm{~s}, 54^{\circ} \mathrm{C}$ for $1 \mathrm{~min}$, and $72^{\circ} \mathrm{C}$ for $1 \mathrm{~min}$. 
Table 1. Primer sequences used in this study.

\begin{tabular}{ll}
\hline Primer name & 5'-3' Sequence \\
\hline ACS-F & ACAGCTCCAATGGCTTCCAACT \\
ACS-R & GAAACAAGACTGAAACTTGACATTCTTCT \\
M13-F & GAGCGGATAACAATTTCACACAGG \\
M13-R & CGCCAGGGTTTCCCAGTCACGAC \\
3'-RACE-1 & TCTCTGATCTCATCACCAATGCTGTCTCCG \\
3'-RACE-2 & CAGAGTTGGTGCTCTGTATTCTTACAATGACAGAG \\
5'-RACE-1 & GAAGAGAAATTGATGCAGTGGTGCCGAGAGG \\
5'-RACE-2 & GAGAGAGTGAGTTGGAAGCCATTGGAGC \\
ACS_orf-F & CGCGGATCCATGTCAACAGTGTTTGTTAATG (underlined sequence digested by BamHI) \\
ACS_orf-R & CGCGTCGACTTAAACATTCTTCTTCTTCCTCT (underlined sequence digested by SalI) \\
Actin-F & GCAACATTGTTCTTAGCGGAGGCT \\
Actin-R & TCTTCATGCTGCTTGGTGCAAGTG \\
ACS-RT-F & CGGCACCACTGCATCAATTTCTCT \\
ACS-RT-R & TGAGATCAGAGACGCAGGCAAAGT \\
\hline
\end{tabular}

The polymerase chain reaction (PCR) products were purified with the TaKaRa Agarose Gel DNA Purification Kit Ver.2.0 [TaKaRa Biotechnology (Dalian) Co., Ltd., Dalian, Liaoning Province, China] and ligated into the pMD 18-T vector according to the manufacturer instructions. The ligation products were transformed into Escherichia coli $\mathrm{DH} 5 \alpha$ cells. Recombinant bacteria were selected and the DNA sequences were determined. In order to obtain the full-length nucleotide sequence of OnACS1, rapid amplification of cDNA ends (RACE)-PCR was performed using the 3'-full RACE Core Set and the 5'-full RACE Core Set (Takara, China) according to the user manual. The 3'-end fragments were amplified using specific primers 3'-RACE-1 and 3'-RACE-2, and the 5'-end fragments were amplified using 5'-RACE-1 and 5'-RACE-2. Each primer was designed based on the nucleotide sequences of the cDNA fragments obtained from the reverse transcription (RT-PCR) described above (Table 1). The PCR products were purified, ligated into the pMD 18-T vector, introduced into E. coli $\mathrm{DH} 5 \alpha$, and sequenced. The full-length sequence of OnACS1 was obtained with 5 '-end fragments, the cDNA fragments, and 3'-end fragments using the DNAman software. Amino acid sequence analysis and multiple sequence alignment were accomplished using the DNAman and Bioedit software. Phylogenetic analysis of ACS amino acid sequences was conducted using the MEGA software.

\section{Expression of recombinant proteins}

The open reading frame (ORF) of OnACS1 was analyzed with the ORF finder software. The coding region of the OnACS1 gene was amplified by PCR using the following two primers (Table 1): ACS_orf-F (sense) contains a BamHI restriction site (underlined) immediately upstream of the ATG translation initiation codon, and ACS_orf-R (antisense) was constructed with a SalI restriction site (underlined) located downstream of the stop codon of the OnACS1 ORF. The PCR product was verified by sequencing, digested with the appropriate restriction enzymes, and directionally ligated into the corresponding sites of the pGEX-6P-1 expression vector system. The resulting plasmid was introduced into $E$. coli BL21 competent cells, and the transformed cells were cultured at $37^{\circ} \mathrm{C}$ in liquid Luria-Bertani medium with $100 \mathrm{mg} / \mathrm{mL}$ ampicillin. Isopropyl-1-thio-b-D-galactoside (IPTG) was added to the shaking culture to a final concentration of $1 \mathrm{mM}$. The cells were harvested for sodium dodecyl sulfate polyacrylamide gel electrophoresis (SDS-PAGE) analysis when the cell density reached an optical density at $600 \mathrm{~nm}$ of $0.6-0.8$. 


\section{ACS activity assay}

After incubation at $28^{\circ} \mathrm{C}$ for $4 \mathrm{~h}, 100-250 \mathrm{~mL}$ cell culture was harvested by centrifugation at $5000 \mathrm{~g}$ for $10 \mathrm{~min}$ at $4^{\circ} \mathrm{C}$. The pelleted cells were sonicated after being suspended in ACS extraction buffer [100 mM Tris- $\mathrm{HCl}, \mathrm{pH} 8.5,4 \mathrm{mM}$ dithiothreitol (DTT), $20 \mu \mathrm{M}$ pyridoxal phosphate (PLP), $2 \mathrm{mM}$ ethylenediaminetetraacetic acid (EDTA), and $0.5 \mathrm{mM}$ phenylmethylsulfonyl fluoride]. Following cell disruption, the debris was removed by centrifugation at $10,000 \mathrm{~g}$ for $10 \mathrm{~min}$ at $4^{\circ} \mathrm{C}$. The supernatant was used for the ACS activity assay.

The ACS activity assay was performed essentially according to the method described by Lizada and Yang (1979). The standard reaction mixture comprised $1 \mathrm{~mL}$ reaction buffer (50 $\mathrm{mM}$ Tris-HCl, $\mathrm{pH}$ 8.0, $20 \mu \mathrm{M}$ PLP, and $4 \mathrm{mM}$ DTT), $200 \mu \mathrm{L}$ SAM, and $50 \mu \mathrm{L}$ ACS extraction buffer (the supernatant described above). The mixture was incubated at $30^{\circ} \mathrm{C}$ for $30 \mathrm{~min}$ and quenched by addition of $50 \mu \mathrm{L} 100 \mathrm{mM} \mathrm{HgCl}_{2}$.

The reaction mixture was sealed, injected with $0.3 \mathrm{~mL}$ mixture of $5 \% \mathrm{NaClO}$ and saturated $\mathrm{NaOH}$ solutions $(2: 1)$, blended fully, and cooled in an ice bath for $2.5 \mathrm{~min}$. After vigorous shaking, the ethylene samples were collected and determined using an Agilent 6890 gas chromatograph (Agilent, USA) equipped with a flame ionization detector. The operation parameters were as follows: column temperature $100^{\circ} \mathrm{C}$; detector temperature $150^{\circ} \mathrm{C}$; carrier gas, hydrogen at $50 \mathrm{~mL} / \mathrm{min}$; make-up, nitrogen gas at $50 \mathrm{~mL} / \mathrm{min}$; air flow at $400 \mathrm{~mL} / \mathrm{min}$; and holding time of $2.5 \mathrm{~min}$. Each sample $(1000 \mu \mathrm{L})$ was injected into the gas chromatograph, and all measurements were done in triplicate.

\section{Fluorescence quantitative PCR analysis}

In order to study the differential expression of OnACS1, the OnACS1 transcript levels were determined by fluorescence quantitative PCR analysis of the total RNA fractions that were obtained from the different organs of Oncidium Gower Ramsey "Gold2" plants and the sepals and gynandria that were treated with ethephon. The RT reaction was conducted in a reaction mixture containing $2 \mu \mathrm{L}$ total RNA, $1 \mu \mathrm{L} 50 \mu \mathrm{M}$ Oligo dT Primer, $4 \mu \mathrm{L} 5 \mathrm{X}$ PrimeScript Buffer, $1 \mu \mathrm{L}$ PrimeScript RT Enzyme Mix I, $1 \mu \mathrm{L} 100 \mu \mathrm{M}$ Random 6-mers, and $11 \mu \mathrm{L}$ RNase-free $\mathrm{dH}_{2} \mathrm{O}$ in a total volume of $20 \mu \mathrm{L}$. The RT reaction was incubated for $15 \mathrm{~min}$ at $37^{\circ} \mathrm{C}$ and for $5 \mathrm{~s}$ at $85^{\circ} \mathrm{C}$. The real-time PCR was performed in a reaction volume of $20 \mu \mathrm{L}$ containing $2.0 \mu \mathrm{L}$ RT reaction product, $0.4 \mu \mathrm{L}$ each of the upstream and downstream primers (ACS-RT-F and ACS-RT-R, 10 $\mu \mathrm{M}), 10 \mu \mathrm{L} 2 \mathrm{X}$ SYBR Premix Ex Taq II, $0.4 \mu \mathrm{L} 50 \mathrm{X}$ ROX Reference Dye or DYE II, and $6.8 \mu \mathrm{L}$ $\mathrm{dH}_{2} \mathrm{O}$ with a 7500 Real-Time PCR System (Applied Biosystems, USA). The PCR was carried out for $30 \mathrm{~s}$ at $95^{\circ} \mathrm{C}$, followed by 40 cycles of $5 \mathrm{~s}$ at $95^{\circ} \mathrm{C}$ and $34 \mathrm{~s}$ at $60^{\circ} \mathrm{C}$, and supplemental incubation for $15 \mathrm{~s}$ at $95^{\circ} \mathrm{C}, 60 \mathrm{~s}$ at $60^{\circ} \mathrm{C}$, and $15 \mathrm{~s}$ at $95^{\circ} \mathrm{C}$. Absolute values for transcript abundance from RT-PCR were quantified using the $2^{-\Delta \Delta C T}$ method by Kenneth and Thomas (2001).

\section{RESULTS}

\section{Isolation and characterization of the $O n A C S 1$ gene}

Using the total RNA isolated from the floral tissues as a template, the first strand of cDNA was amplified. Using the conservative sequence of the registered ACS genes of Cattleya (accession No. AY504664), Dendrobium (accession No. EF488013), and Phalaenopsis (acces- 
sion No. AF004663), the gene-specific primers ACS-F and ACS-R were designed. Following 30 cycles of PCR amplification using the first strand of cDNA that was synthesized as a template, a product of the expected size (400 bp) was easily visualized with $1 \%$ agarose gel electrophoresis (data not shown). Nested PCR primers were used to amplify ACS sequences in two rounds of PCR using 3'-RACE-1 and 5'-RACE-1 as the first-round primers and 3'-RACE-2 and 5'-RACE2 as the second-round primers. Then, $3^{\prime}$ fragments of $720 \mathrm{bp}$ and $5^{\prime}$ fragments of $700 \mathrm{bp}$ were obtained (data not shown). The resulting PCR products described above were sequenced and spliced to obtain the full-length cDNA with the DNAman software (DNAMAN 6.0, USA). The full-length cDNA was verified with amplification of the coding region of the OnACS1 gene, agarose gel electrophoresis, and subsequent sequencing (data not shown). The OnACS1 gene sequence is $1586 \mathrm{bp}$ and contains a 1308-bp ORF encoding 436 amino acids (Figure 1). The ORF is preceded by a 5' UTR of $105 \mathrm{bp}$ and followed by a 3' UTR of $173 \mathrm{bp}$. A comparison of the deduced OnACS1 amino acid sequence and amino acid sequences for ACSs from other plants revealed that the Oncidium ACS protein shares 85, 84, and 83\% homology with ACS proteins of Cattleya bicolor (accession No. AAR88653), Dendrobium crumenatum (accession No. AAB67882), and Phalaenopsis hybrid (accession No. AAR00507), respectively. Phylogenetic analysis of amino acid sequences of plant ACSs (Figure 2) shows that the Oncidium ACS protein is clustered with the ACS proteins of Cattleya bicolor, Dendrobium, and Phalaenopsis orchids. Therefore, we designed the Oncidium ACS as OnACS1 (GenBank accession No. JQ822087).

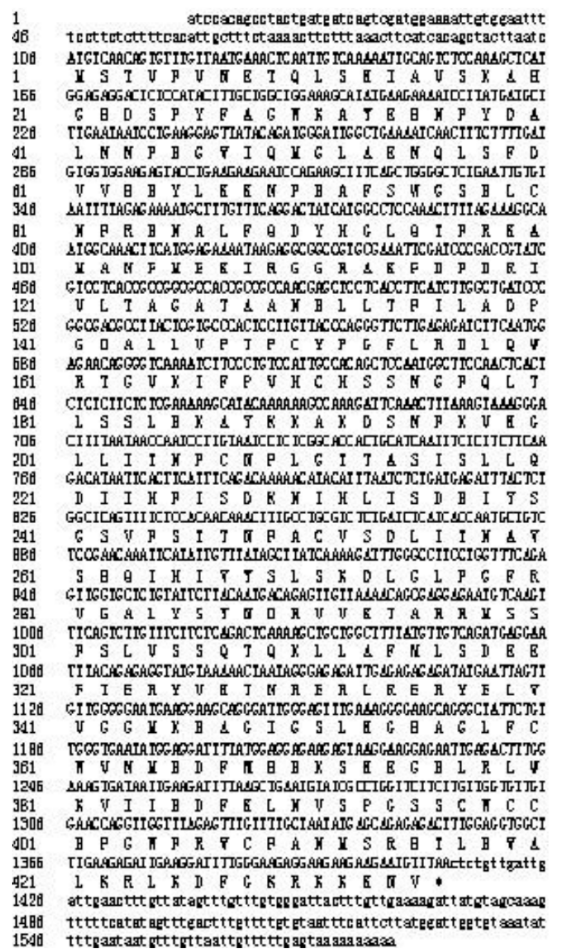

Figure 1. Nucleotide sequence and predicted protein sequences of OnACS1. The open reading frame is indicated by upper case letters. The 5' and 3' untranslated regions are indicated by lower case letters. The deduced amino acid sequence is given in upper case letters under the nucleotide sequence. The translation stop codon is indicated by an asterisk. 


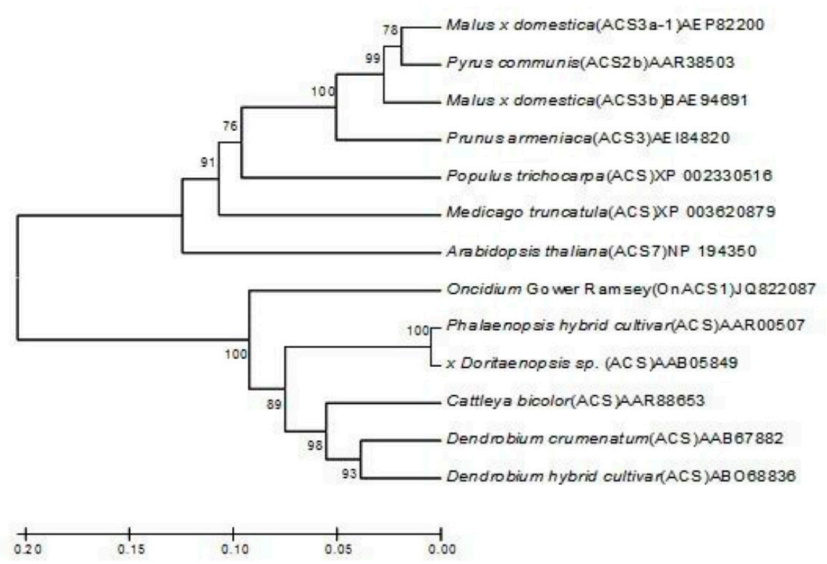

Figure 2. Phylogenetic analysis of amino acid sequences of plant ACC synthase family. The phylogenetic tree constructed from an optimal alignment of proteins using the MEGA software. Numbers represent amino acid sequence identity between members of the subfamily.

\section{Analysis of OnACS1 prokaryotic expression and enzymatic activity}

Expression analysis of recombinant OnACS1 was conducted with a translational fusion of the OnACS1 ORF into E. coli using the prokaryotic expression vector pGEX-OnACS1. SDS-PAGE analysis showed specific expression that was induced by $1 \mathrm{mM} \mathrm{IPTG}$ at $37^{\circ} \mathrm{C}$ for $4 \mathrm{~h}$. The molecular weight of the protein agreed with the size of the predicted protein (Figure 3). The gas chromatographic results revealed that a small peak appeared, indicating that ethylene production could be detected, and the enzymatic activity of the recombinant OnACS1 protein was determined (data not shown).

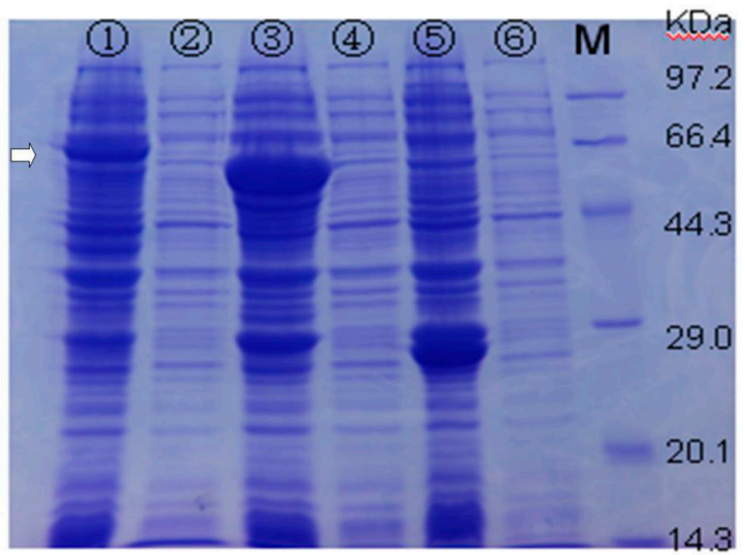

Figure 3. SDS-PAGE analysis of recombinant OnACS1. Lane $1=$ pGEX-OnACS1 proteins from cells induced by IPTG $(1 \mathrm{mM})$ at $37^{\circ} \mathrm{C}$ for $4 \mathrm{~h}$. Arrow indicates the expected band for the pGEX-OnACS1 proteins; lane 2 $=$ pGEX-OnACS1 proteins from uninduced Escherichia coli; lane $3=$ pGEX-OnACO1 from cells induced by IPTG $(1 \mathrm{mM})$ at $37^{\circ} \mathrm{C}$ for $4 \mathrm{~h}$; lane $4=$ pGEX-OnACO1 proteins from uninduced $E$. coli; lane $5=$ Proteins from cells transformed with the empty vector pGEX induced by IPTG $(1 \mathrm{mM})$ at $37^{\circ} \mathrm{C}$ for $4 \mathrm{~h}$; lane $6=$ Proteins from uninduced transformed with the empty vector pGEX; lane $M=$ molecular weight marker 


\section{Analysis of OnACS1 gene expression with fluorescence quantitative PCR}

The expression of the OnACS1 gene in various tissues of Oncidium Gower Ramsey "Gold2" was investigated with fluorescence quantitative PCR analysis. The expression of the OnACS1 gene predominantly occurred in gynandria, and lower levels of OnACS1 gene expression were detected in roots, stems, leaves, lip, petals, and sepals, and the OnACS1 expression was slightly higher in the sepals than in the other tissues (Figure 4). The effects of ethephon treatment of the floral tissues on OnACSI gene expression in the gynandria and sepals were studied. OnACS1 gene expression increased in the sepals with the duration of ethephon treatment, and expression slightly increased in the gynandria in response to ethephon (Figure 5).

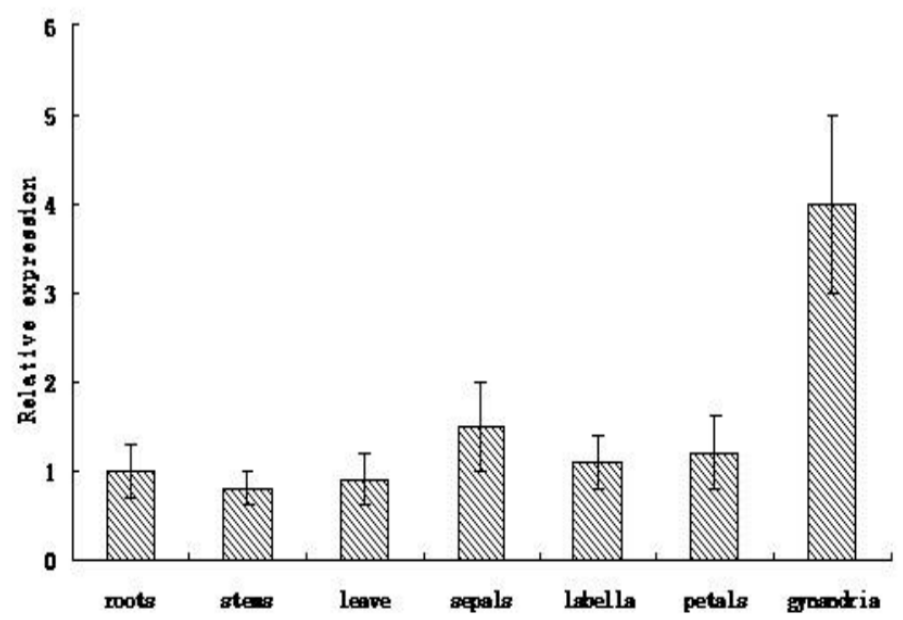

Figure 4. Expression of OnACS1 gene in various tissues of Oncidium Gower Ramsey "Gold2" determined by fluorescence quantitative PCR analysis. Values are reported as means of three replicates $\pm \mathrm{SE}$.

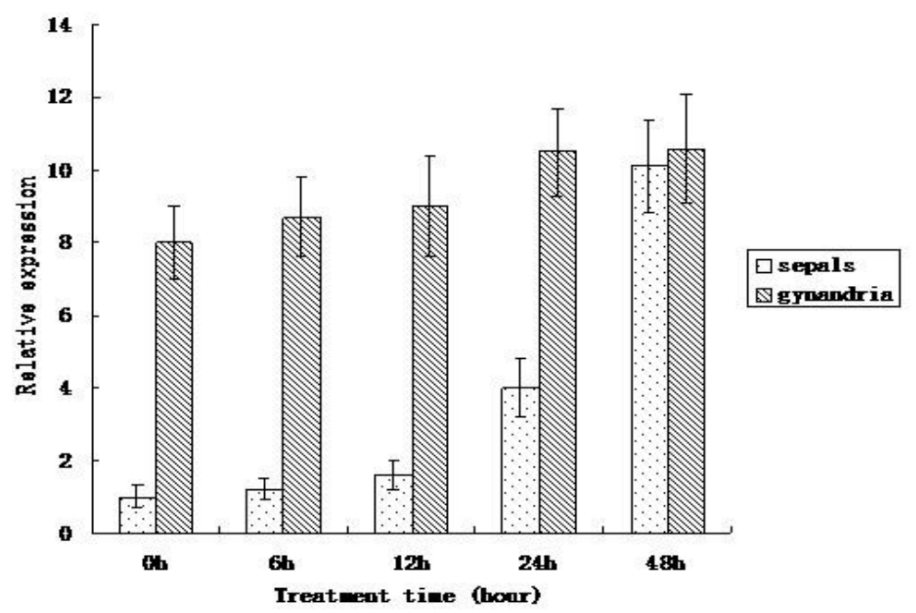

Figure 5. Changes in OnACS1 gene expression in gynandria and sepals after treatment of the floral tissues with $1 \%$ ethephon for different time. Values are reported as means of three replicates $\pm \mathrm{SE}$. 


\title{
DISCUSSION
}

In this report, the full-length cDNA of OnACS1 was isolated and sequenced from Oncidium flowers by the RT-PCR and RACE methods. The ORFs of the reported ACS genes are generally $1200-1300$ bp and encode about 430 amino acids, including the Dendrobium ACS gene (AAB67882) encoding 435 amino acids and the Cattleya ACS gene (AAR88653) encoding 434 amino acids. The cloning and characterization of the OnACS1 gene indicated its ORF is $1308 \mathrm{bp}$ and encodes 436 amino acids. Alignments of deduced amino acid sequences of ACC synthases from Oncidium with those of Cattleya bicolor, Dendrobium crumenatum, and Phalaenopsis hybrid showed that these sequences share high identity and are highly conserved. These results indicate that the cloned gene is a typical member of the Oncidium ACS gene family. Analysis of OnACS1 prokaryotic protein expression and enzymatic activity further confirmed this.

Many studies reported that the ACS genes display distinct spatial and temporal expression patterns (ten Have and Woltering 1997; Trebitsh et al., 1997; Bui and O'Neill, 1998; Jones and Woodson, 1999; Yamasaki et al., 2001; Yamagami et al., 2003; Tsuchisaka and Theologis, 2004; Peng et al., 2005; Salman-Minkov et al., 2008). The expression of the OnACS1 gene in all tissues tested suggests that it is constitutively expressed but at different levels: high levels in gynandria, moderate levels in sepals, and low levels in other organs. Ethephon, a chemical that can be converted into ethylene upon metabolism by the plant, significantly promoted OnACS1 gene expression in the sepals and slightly promoted expression in the gynandria. These results demonstrated that it was differentially regulated in a tissue-specific manner. Moreover, OnACS1, as an ethylene biosynthetic gene, was induced by ethephon treatment, indicating that ethylene is the main regulator of its expression. A detailed study of the role of OnACS1 in ethylene production and floral senescence of Oncidium is underway.

\section{ACKNOWLEDGMENTS}

\author{
Research supported by the Hainan University Fund (\#2012hckled-7).
}

\section{REFERENCES}

Abeles FB, Morgan PW and Saltveit ME Jr (1992). Ethylene in Plant Biology. 2nd edn. Academic Press, New York.

Adams DO and Yang SF (1979). Ethylene biosynthesis: Identification of 1-aminocyclopropane-1-carboxylic acid as an intermediate in the conversion of methionine to ethylene. Proc. Natl. Acad. Sci. U. S. A. 76: 170-174.

Bui AQ and O'Neill SD (1998). Three 1-aminocyclopropane-1-carboxylate synthase genes regulated by primary and secondary pollination signals in orchid flowers. Plant Physiol. 116: 419-428.

Henskens JAM, Rouwendal GJ, ten Have A and Woltering EJ (1994). Molecular cloning of two different ACC synthase PCR fragments in carnation flowers and organ-specific expression of the corresponding genes. Plant Mol. Biol. 26: 453-458.

Jones ML and Woodson WR (1999). Differential expression of three members of the 1-aminocyclopropane-1-carboxylate synthase gene family in carnation. Plant Physiol. 119: 755-764.

Kende H (1993). Ethylene biosynthesis. Annu. Rev. Plant Physiol. 44: 283-307.

Kenneth JL and Thomas DS (2001). Analysis of relative gene expression data using real-time quantitative PCR and the 2- $\triangle \mathrm{CCT}$ method. Methods 25: 402-408.

Lin Z, Zhong S and Grierson D (2009). Recent advances in ethylene research. J. Exp. Bot. 60: 3311-3336.

Lizada MC and Yang SF (1979). A simple and sensitive assay for 1-aminocyclopropane-1-carboxylic acid. Anal. Biochem. 100: $140-145$.

Park KY, Drory A and Woodson WR (1992). Molecular cloning of an 1-aminocyclopropane-1-carboxylate synthase from senescing carnation flower petals. Plant Mol. Biol. 18: 377-386. 
Peng HP, Lin TY, Wang NN and Shih MC (2005). Differential expression of genes encoding 1-aminocyclopropane-1carboxylate synthase in Arabidopsis during hypoxia. Plant Mol. Biol. 58: 15-25.

Salman-Minkov A, Levi A, Wolf S and Trebitsh T (2008). ACC synthase genes are polymorphic in watermelon (Citrullus spp.) and differentially expressed in flowers and in response to auxin and gibberellin. Plant Cell. Physiol. 49: 740-750.

ten Have A and Woltering EJ (1997). Ethylene biosynthetic genes are differentially expressed during carnation (Dianthus caryophyllus L.) flower senescence. Plant Mol. Biol. 34: 89-97.

Trebitsh T, Staub JE and O’Neill SD (1997). Identification of a 1-aminocyclopropane-1-carboxylic acid synthase gene linked to the female (F) locus that enhances female sex expression in cucumber. Plant Physiol. 113: 987-995.

Tsuchisaka A and Theologis A (2004). Unique and overlapping expression patterns among the Arabidopsis 1-aminocyclopropane-1-carboxylate synthase gene family members. Plant Physiol. 136: 2982-3000.

Yamagami T, Tsuchisaka A, Yamada K, Haddon WF, et al. (2003). Biochemical diversity among the 1-aminocyclopropane-1-carboxylate synthase isozymes encoded by the Arabidopsis gene family. J. Biol Chem. 278: $49102-$ 49112.

Yamasaki S, Fujii N, Matsuura S, Mizusawa H, et al. (2001). The M locus and ethylene-controlled sex determination in andromonoecious cucumber plants. Plant Cell. Physiol. 42: 608-619.

Yang GH and Liu JP (2011). Comparison of two RNA extraction methods of coconut tree. Chin. J. Trop. Agric. 1: 51-54.

Yang SF and Hoffman NE (1984). Ethylene biosynthesis and its regulation in higher plants. Anпи. Rev. Plant Agric. Physiol. 35: 155-189.

Zarembinski TI and Theologis A (1994). Ethylene biosynthesis and action: a case of conservation. Plant Mol. Biol. 26: 1579-1597. 